Bull. Fac. Agric., Cairo Univ.,65: 344-359 (2014).

\title{
INDISCRIMINATE USE AND IMPROPER APPLICATION OF PESTICIDES BY JORDANIAN VEGETABLE AND FRUIT FARMERS
}

\author{
(Received: 30.11.2014)
}

By

F. A. Al-Zyoud

\author{
Department of Plant Protection and IPM, Faculty of Agriculture, Mu'tah University, Karak, Jordan
}

\begin{abstract}
The majority of Jordanian farmers do not understand the harmful effects that pesticides have on health and environment. The fate and impact of pesticide application in Jordan remain unknown in the public and farmer eye. For this purpose, Jordanian farmers were questioned about their social aspects, types of pests encountered, and pesticide knowledge, practices, safety and resources by conducting a country-wide survey of farmers during 2014. The results revealed that $66 \%$ of respondents had good knowledge of pesticide use, and $85 \%$ of them read the label before applying pesticides. Approximately $56 \%$ of the farmers applied pesticides when necessary, while $29 \%$ applied pesticides weekly. A very high percentage (93\%) of farmers believed that they will still apply pesticides in the coming years. Almost $74 \%$ of the farmers were found to use both preventive and cure pesticide, $73 \%$ applied pesticide at the morning and only $39 \%$ at the evening. Medium pesticide' rate was applied by $59 \%$ and higher rate by $38 \%$ of the farmers. The data indicated that a wide variety of chemicals were being applied by the farmers. Using bio-pesticide had less importance by farmers. The farmers had faced many pesticide-related illnesses and injuries. About $14 \%$ of farmers did not wear protective cloths during application, $11 \%$ stored pesticide in house, 58\% burned empty containers, and $39 \%$ did not keep any records. Private consultants and pesticide' companies (42\%) were the most popular source of information. Almost 25\% of farmers had been involved in pesticide' training program, and $78 \%$ reported seeking for information about pesticide. On the other hand, education was positively and significantly correlated with knowledge of pesticide use and farmers involvement in pesticides training programs, while reading label was positively and significantly correlated with education and negatively with age. There was a positive and significant correlation between involvement in pesticides training program and knowledge of pesticides use. In conclusion, farmers depend heavily on pesticides use for pest control, and the survey has shown some overuse, misuse and abuse of pesticides.
\end{abstract}

Key words: pesticides, indiscriminate use, improper application, vegetables, fruit trees, environment, human health, Jordan.

\section{INTRODUCTION}

Quality and quantity of agricultural crops are affected by hundreds of pests found in the agroecosystem. Pests cause a loss of half of the world's food crops (Sheikh et al., 2011). The increasing global food demands have led to a constant battle for higher crop yields. The main method of pest control adopted by the majority of farmers is often the erroneous and abusive application of pesticides (Song and Swinton, 2009., Naveed, 2011., Al-Zyoud, 2014). Pesticides helped the world meets growing food demand by increasing agricultural productivity through controlling pests. The global market of pesticides was over 52 billion US dollars in 2009 (Market Study-Crop Protection, 2012). Furthermore, there were more than 1,055 active ingredients registered as pesticides (Goldman, 2007). The number of pesticides registered and imported in Jordan is 506 with a total quantity of 2,055 metric tons (Jordan Statistical Yearbook, 2012).

The complete dependency, extensive and massive use of pesticides in modern agriculture caused their widespread diffusion to all environmental compartments including a wide 
range of organisms up to the humans (Samiee et al., 2009., Abang et al., 2013). Ideally, a pesticide must be lethal to the target pests, but not to non-target organisms. Unfortunately, this is not the case, so the controversy of use and abuse of pesticides has surfaced. On the other hand, it has been estimated that 3 million cases of pesticide poisoning, 220,000 of which are fatal, occur world-wide every year (Raipulis et al., 2009). Exposure to pesticides is increasingly linked to human health effects, i.e. immune suppression, reproductive abnormalities, nervous system disorders (Hanke and Jurewicz, 2004; Frazier, 2007), cancer (Weichenthal et al., 2010; Amanullah and Hari, 2011), asthma and diabetes (Lee et al., 2006; Jayashree and Singhi., 2011). It is reported that transport of pesticides by surface runoff during rainfall is a major process contributing to pesticide contamination of rivers (Morohashi et al., 2012), and groundwater (Sorensen et al., 2011). Almost high doses and frequent pesticide applications have adversely affected natural enemies (Al-Zyoud, 2012, 2014), birds (Tanabe et al., 1998), wildlife (Espin et al., 2010), beneficial soil microorganisms, plant yields (Glover-Amengor and Tetteh, 2008), caused phytotoxicity (Fishel, 2011), and contributed to ozone depletion (Giri, 1998). The pesticides' misuse can also cause undesirable residue accumulation in food crops (Caldas et al., 2011), acute and chronic health problems to human (Firestone et al., 2005).

Farmers use pesticides without full understanding of the impact on human health and environment (Ngowi, 2003). While, for instance, it is doubtful whether farmers follow the recommended application rate of pesticides. In addition, their observation of the pre-harvest spraying time interval, proper disposal of agrochemical wastes and empty containers are questionable. They also lack the appropriate knowledge on safe handling and use of pesticides (Ngowi et al., 2007). Extensive use of pesticides with residual contents exceeding the maximum residue limits on produce, urged many European countries to ban certain agricultural exports from several Arab countries (Bashour, 2008). In Jordan, like other Arab countries, the uncontrolled use, handling and misuse of pesticides are well known. Several studies on various awareness aspects associated with pesticide use have been conducted among farmer populations worldwide including the developing countries (Clarke et al., 1997; Wesseling et al., 1997; Perry et al., 2000 ;Yassin et al., 2002).
However, pesticide use comes at a significant cost. What is required is to weight all the risks against the benefits to ensure a maximum margin of safety. Our approach to the use of pesticides should be pragmatic. In other words, all activities concerning pesticides should be based on scientific judgment, not on commercial considerations. The problem is all the more serious as this field of knowledge has significant gaps, not only as regards Jordan literature but also on a global scale. It is to be mentioned that the majority of Jordanian farmers do not understand the harmful effects that pesticides have on health and environment. They overestimate their benefits and use higher doses and more frequent than necessary (Al-Zyoud, 2014). The fate and impact of pesticide application in Jordan remain unknown in the public and farmer eye. Thus, farmers' perception of pesticide practices and, their level of awareness of adverse effects on the environment and human health needs to be determined. For this purpose, Jordanian vegetables and fruit trees' farmers were questioned about their social aspects, types of pests encountered, and pesticides knowledge, practices, safety and resources by conducting a country-wide survey. This study highlights some aspects on the side effects of pesticides and raise directions deserving further development to create a better understanding of safe application of pesticides in agriculture.

\section{MATERIALS AND METHODS}

\subsection{Questionnaire development}

For the questionnaire, proposed questions were developed in Arabic language and sent to a various pesticides' specialists for their critique and suggested additions. After responses were received from the specialists, their suggestions and comments were utilized in developing the final questionnaire. The survey questionnaire instrument was developed to document the current indiscriminate use and improper application of pesticides by vegetables and fruit trees' farmers in Jordan. The questionnaire was sent to 120 randomly selected vegetables and fruit trees' farmers to determine to what extent they used pesticides. Although sampling was random, an effort was made to ensure that the selected farmers represented different locations, age groups, farm sizes and literally levels. The paper format questionnaire was accompanied by a cover letter. The target of the study was explained to these respondents through the cover 
letter to seek their consent. This was done in order to ensure their cooperation, which was very important for the study. In addition, followup phone calls and visits, when necessary, to non-respondents were done to encourage their participation. Also, several phone calls were made to the participants to explain any unclear question in the questionnaire. The study was carried out by survey during 2014.

\subsection{Structure of the survey data}

For addressing the indiscriminate use and improper application of pesticides by vegetables and fruit trees' farmers, the questionnaire used in this survey consisted of three main parts; demographics of the farmers, main pest problems occurring in the farmers' farms, and the indiscriminate use and improper application of pesticides. The first five questions in the questionnaire determined the demographics of the farmers, i.e. location, age, agricultural experience and educational level of the farmers, and the number of greenhouses/farm size. Question seven probed into main pest problems (diseases, insects, mites and nematodes) occurring in the farmers' farms. Questions eight through forty one were divided into five subsections, and addressed pesticides' applications, types of pesticides used, pesticides' safety, records and resources, respectively. Subsection 1 (question eight to sixteen) determined some issues on pesticides' applications such as reading label carefully before applying pesticides, number of pesticides' applications per growing season/year, location of purchasing pesticides, type of pesticides used whether it preventive or curative, time and rate of application, meteorological considerations during application. Subsection 2 (questions seventeen to twenty) addressed the most commonly used pesticides by farmers, time of purchasing pesticides, amount of money spent for pesticides' purchases and the most types of pesticides used by the farmers. Subsection 3 on pesticides' safety (question twenty one to thirty four) asked farmers about care of side effects of pesticides on human health, environmental and groundwater. In addition, in the $3^{\text {rd }}$ subsection, farmers were also asked in details about toxicity level of the pesticides used, resistance management, using selective, non-persistence, systemic and bio-pesticides, time of application and wait for the safety period of pesticides. Furthermore, the farmers were asked if they have faced pesticide-related illnesses/injuries after applying pesticides, or have heard about the side effects of extensive use of pesticides, and where they store pesticides? and the fate of empty containers. Subsection 4 (question thirty five) on pesticides' records asked farmers if they keep records of pesticide use in their farms. Subsection 5 (question thirty six to forty one) addressed farmers' resources of pesticides, involvement in training pesticides' workshop/program, if they seek for pesticides information and how they would like to have these information? A series of yes/no answers, agree/disagree answers, and never, seldom, sometimes, often and always answers were included in the questionnaire.

\subsection{Response outcome and statistical analysis}

One hundred and four completed questionnaires were returned undergone an initial evaluation of the returned surveys for completeness, and farm specific identification information were removed. Data obtained from all completed questionnaires were compiled in a spreadsheet, and were coded. In order to code the data, the respondents reported answers of implementation (that is, not implementing a practice $=0$ or implementing a practice $=1$ ). Respondents were asked how frequently or intensively each item was practiced. A codification manual was prepared and numbers ranging from 1 to 5 were assigned to the possible responses, never, seldom, sometimes, often and always, respectively. The final point value of each item was obtained by multiplying the assigned value by the number of responses, and because multiple choices could be checked by each respondent in some questions, percentages do not sum to 100 . The data were analyzed using descriptive and inferential statistics such as mean, standard error mean, percentages and frequencies (Samiee et al., 2009). On the other hand, descriptive analysis provides statistics that are used to describe the basic features of the data in the study. For correlation of education level with other variables, the illiterate, schooling, tawjihi, diploma, BSc and MSc were assigned values of $1,2,3,4,5$ and 6 , respectively. The spearman's correlation analysis procedure was used to examine pair-wise associations between demographics' variables of the farmers (age, experience, education and farm size) and particular pesticides practice (Zar, 1999). All analyses were performed using the Proc GLM of the statistical package SigmaStat version 17.0 (SPSS, 1997). 


\section{RESULTS}

3.1. Demographics of the respondents

\subsubsection{Respondents' geographical distribution and their age}

Survey responses were obtained from 104 respondents representing seven governorates in Jordan. The highest percentage of responses was obtained from Balqa (36.54\%)., meanwhile the lowest responses' percentage was recorded for Madaba with only $1.92 \%$ (Table 1 ). These data revealed a satisfactory cross-section through the country. The overall average farmers' age was estimated at $43.86 \pm 1.08$ years old, in which the youngest farmer was 22 years old and the eldest was 75 years old. Splitting the farmers age into groups (Table 1) showed that the majority of farmers is in their forties $(41.35 \%)$, while the minority of the farmers was in their seventies $(2.88 \%)$. On the average, survey respondents were middle-aged.

\subsubsection{Farm size and agricultural experience of respondents}

The overall total area owned by respondents was 6,163 dunums with an overall average of $59.26 \pm 10.57$ dunums/farmer. Of this area, $2,063.5$ dunums $(33.48 \%)$ were protected $(4,127$ greenhouses). Splitting the farm size into groups showed that the majority of farmers $(78.85 \%)$ owned an average of $21.20 \pm 1.53$ dunums/farmer (Table 2). In contrast, only $6.73 \%$ of the farmers had an average area of $411.71 \pm 61.25$ dunums/farmer. The total number of years of farmers experience in agriculture was 1,803 years with an overall average of $17.34 \pm 0.89$ years/farmer. The majority of the farmers (almost 44\%) had an average of 16.1 years of experience, while only $6.73 \%$ of respondents had an average experience of $36.86 \pm 1.12$ years/farmer (Table 2).

Table (1): Geographical representation of respondents $(n=104)$ according to governorate, and groups for respondents' age.

\begin{tabular}{lccccc}
\hline Governorate & $\begin{array}{c}\text { Frequency of } \\
\text { farmers }\end{array}$ & \% of farmers & $\begin{array}{c}\text { Age interval } \\
\text { (years) }\end{array}$ & $\begin{array}{c}\text { Frequency } \\
\text { of farmers }\end{array}$ & \% of farmers \\
\hline Balqa & 38 & 36.54 & $<20$ & 00 & 00.00 \\
Karak & 28 & 26.92 & $20-29$ & 05 & 04.81 \\
Mafraq & 21 & 20.19 & $30-39$ & 27 & 25.96 \\
Irbid & 07 & 06.73 & $40-49$ & 43 & 41.35 \\
Amman & 04 & 03.85 & $50-59$ & 18 & 17.31 \\
Jarash & 04 & 03.85 & $60-69$ & 08 & 07.69 \\
Madaba & 02 & 01.92 & $\geq 70$ & 03 & 02.88 \\
\hline
\end{tabular}

Table (2): Groups for farm size owned by respondents (n=104) and their agricultural experience.

\begin{tabular}{|c|c|c|c|}
\hline Farm size (dunum) & $\begin{array}{l}\text { Aver. farm size } \\
\text { (dunum) }\end{array}$ & Frequency of farmers & $\%$ of farmers \\
\hline $1-50$ & $21.20 \pm 1.53$ & 82 & 78.85 \\
\hline $51-100$ & $92.07 \pm 3.51$ & 14 & 13.46 \\
\hline $101-200$ & $200.00 \pm 0.00$ & 01 & 00.96 \\
\hline$\geq 201$ & $411.71 \pm 61.25$ & 07 & 06.73 \\
\hline Experience interval & Aver. no. of years & Frequency of farmers & \% of farmers \\
\hline 1-10 years & $06.96 \pm 0.53$ & 28 & 26.92 \\
\hline 11-20 years & $16.09 \pm 0.42$ & 46 & 44.23 \\
\hline 21-30 years & $26.52 \pm 0.65$ & 23 & 22.12 \\
\hline Above 30 years & $36.86 \pm 1.12$ & 07 & 06.73 \\
\hline
\end{tabular}


Educational level of schooling was the most dominant among the farmers with $28.85 \%$, followed by Tawjihi (25.0\%) and BSc University graduate (21.15\%) (Table 3). Meanwhile, university graduates of M.Sc. level $(2.88 \%)$ was the lowest among the respondents.

3.2. Occurrence of main pest problems in the respondents' farms

Pests occurred intensively in the respondents' farms during the survey period. On vegetables, about $70 \%$ of interviewed farmers cited whiteflies, spider mites and powdery mildew as the most important pests in their farms (Table 4).

While, Verticillium wilt (15.38\%) was the least cited by farmers. On fruit trees, olive fruit fly $(35.58 \%)$ and grape powdery mildew $(31.70 \%)$ were the most cited pests by the farmers.

In contrast, apple's scab $(9.62 \%)$ and fire blight $(6.73 \%)$ were the least reported pests (Table 4).

Table (3): Educational level of farmers ( $n=104)$.

\begin{tabular}{lll}
\hline Education level & Frequency of farmers & \% of farmers \\
\hline Illiterate & 06 & 05.77 \\
Schooling & 30 & 28.85 \\
Tawjihi* & 26 & 25.00 \\
Diploma & 17 & 16.35 \\
University graduate, BSc & 22 & 21.15 \\
University graduate, MSc & 03 & 02.88 \\
\hline
\end{tabular}

*Finishing the secondarv school successfullv.

Table (4): Pests present reported by respondents $(n=104)$.

\begin{tabular}{|c|c|c|c|c|c|}
\hline $\begin{array}{l}\text { Pest species } \\
\text { (Vegetables) }\end{array}$ & $\begin{array}{l}\text { Frequency } \\
\text { of farmers }\end{array}$ & $\begin{array}{c}\text { Pest } \\
\text { occurrence } \\
(\%)^{*}\end{array}$ & $\begin{array}{l}\text { Pest species } \\
\text { (Fruit trees) }\end{array}$ & $\begin{array}{l}\text { Frequency } \\
\text { of farmers }\end{array}$ & $\begin{array}{c}\text { Pest } \\
\text { occurrence } \\
(\%)^{*}\end{array}$ \\
\hline Whiteflies & 73 & 70.19 & Olive fruit fly & 37 & 35.58 \\
\hline Spider mites & 73 & 70.19 & Grape powdery mildew & 33 & 31.70 \\
\hline Powdery mildew & 73 & 70.19 & Olive pysalla & 28 & 26.92 \\
\hline Aphids & 68 & 65.38 & Fruit fly & 27 & 25.96 \\
\hline Leafminers & 63 & 60.58 & Grape black rot & 27 & 25.96 \\
\hline Thrips & 59 & 56.73 & Gummosis of citrus trees & 27 & 25.96 \\
\hline Downey mildew & 57 & 54.81 & Olive mites & 25 & 24.04 \\
\hline Early blight & 56 & 53.85 & Grape berry moth & 24 & 23.08 \\
\hline Fusarium wilt & 51 & 49.04 & Grape mites & 24 & 23.08 \\
\hline Late blight & 45 & 43.27 & Olive verticillium wilt & 21 & 20.19 \\
\hline Root knot nematodes & 43 & 41.35 & Apple stem borer & 20 & 19.23 \\
\hline Fruit rot & 39 & $\mathbf{3 7 . 5 0}$ & Golden aphids & 20 & 19.23 \\
\hline Virus diseases & 38 & 36.54 & Capnodius & 19 & 18.27 \\
\hline Bacterial diseases & 21 & 20.19 & Peach leaf curl & 19 & 18.27 \\
\hline Damping-off & 20 & 19.23 & Olive branch knot & 17 & 16.35 \\
\hline \multirow[t]{7}{*}{ Verticillium wilt } & 16 & 15.38 & Apple powdery mildew & 15 & 14.42 \\
\hline & & & Apple fruit moth & 15 & 14.42 \\
\hline & & & Olive leaf spot & 15 & 14.42 \\
\hline & & & Citrus scales & 14 & 13.46 \\
\hline & & & Citrus mealy bugs & 12 & 11.54 \\
\hline & & & Apple scab & 10 & 09.62 \\
\hline & & & Apple fire blight & 07 & 06.73 \\
\hline
\end{tabular}

\footnotetext{
*Because multiple choices could be checked by each respondent, percentages do not sum to 100.
} 
3.3.Indiscriminate use and improper application of pesticides

\subsubsection{Pesticides' applications}

High percent of farmers $(66.35 \%)$ reported that they have good knowledge of pesticide use. Almost $85 \%$ of the farmers read the label before applying pesticides. More than half of the farmers $(55.77 \%)$ applied pesticides when necessary, while $28.85 \%$ applied pesticides weekly (Table 5). A very high percentage $(93.27 \%)$ of the farmers purchased pesticides from local markets, and believed that they will still apply pesticides in the coming years. In regards to the type of pesticide used, $74 \%$ of the farmers applied both curative and preventive pesticides. Almost $73 \%$ of the farmers applied pesticides at the morning and only $39.42 \%$ at the evening. Medium pesticides' rate was applied by $58.65 \%$ and higher rate by $37.50 \%$ of the farmers. Wind speed and direction $(84.62 \%)$ and temperature $(80.77 \%)$ were the most meteorological considerations taken into account during pesticides' application. A high percentage $(75.96 \%)$ of farmers believed that chemicals have rapid action, and enable high level of control of most pests $(72.12 \%)$ (Table5).

Table (5): Some issues related to pesticides' applications as reported by respondents $(\mathrm{n}=104)$.

\begin{tabular}{|c|c|c|c|}
\hline & Item & $\begin{array}{l}\text { Frequency } \\
\text { of farmers }\end{array}$ & $\begin{array}{l}\% \text { of } \\
\text { farmers }\end{array}$ \\
\hline \multirow{2}{*}{$\begin{array}{l}\text { Knowledge of } \\
\text { pesticides use }\end{array}$} & Good knowledge & 69 & 66.35 \\
\hline & Poor knowledge & 35 & 33.65 \\
\hline \multicolumn{2}{|l|}{$\begin{array}{l}\text { Reading label } \\
\text { before application }\end{array}$} & 88 & 84.62 \\
\hline \multirow{8}{*}{$\begin{array}{l}\text { Number of } \\
\text { pesticides' } \\
\text { applications * }\end{array}$} & When necessary & 58 & 55.77 \\
\hline & Weekly & 30 & 28.85 \\
\hline & Every two weeks & 11 & 10.58 \\
\hline & Once a month & 06 & 05.77 \\
\hline & Twice a week & 04 & 03.85 \\
\hline & Three times a week & 02 & 01.92 \\
\hline & Daily & 01 & 00.96 \\
\hline & None & 01 & 00.96 \\
\hline \multirow{3}{*}{$\begin{array}{l}\text { Location of } \\
\text { buying pesticides* }\end{array}$} & Local markets & 97 & 93.27 \\
\hline & Agricultural stations & 05 & 04.81 \\
\hline & Others & 04 & 03.85 \\
\hline \multicolumn{2}{|l|}{$\begin{array}{l}\text { I will still apply } \\
\text { pesticides in the } \\
\text { coming years }\end{array}$} & 97 & 93.27 \\
\hline \multirow{3}{*}{$\begin{array}{l}\text { Type of pesticide } \\
\text { used }\end{array}$} & Both & 77 & 74.04 \\
\hline & Curative & 21 & 20.19 \\
\hline & Preventive & 06 & 05.77 \\
\hline \multirow[t]{4}{*}{ Application time* } & Morning & 76 & 73.08 \\
\hline & Evening & 41 & 39.42 \\
\hline & No specific time & 11 & 10.58 \\
\hline & Mid-day-Afternoon & 06 & 05.77 \\
\hline \multirow[t]{3}{*}{ Application rate* } & Middle rate & 61 & 58.65 \\
\hline & Higher rate & 39 & 37.50 \\
\hline & Lower rate & 07 & 06.73 \\
\hline \multirow{4}{*}{$\begin{array}{l}\text { Meteorological } \\
\text { considerations } \\
\text { during } \\
\text { application* } \\
\end{array}$} & Wind speed and direction & 88 & 84.62 \\
\hline & Temperature & 84 & 80.77 \\
\hline & Rainfall & 68 & 65.38 \\
\hline & Relative humidity & 52 & 50.00 \\
\hline \multirow{5}{*}{$\begin{array}{l}\text { Reasons of using } \\
\text { pesticides?* }\end{array}$} & Rapid action & 79 & 75.96 \\
\hline & Enable high level of control of most pests & 75 & 72.12 \\
\hline & $\begin{array}{l}\text { The only control method when population approach } \\
\text { ETL }\end{array}$ & 70 & 67.31 \\
\hline & Applicable to most pests & 69 & 66.35 \\
\hline & Farmer may apply when and where required & 56 & 53.85 \\
\hline
\end{tabular}

*Because multiple choices could be checked by each respondent, percentages do not sum to 100. 


\subsubsection{Commonly used pesticides}

Almost $40 \%$ of the farmers indicated that they buy pesticides after the appearance of pests, and about $44 \%$ of them paid more than 2,000 JD for purchasing pesticides yearly (Table 6).

The most used agrochemicals by respondents were the insecticides: chlorpyrifos (63.46\%), methomyl (54.81\%) and cypermethrin (49.04\%)., the fungicides: sulphur (56.73\%), zineb $(40.38 \%)$, and carbendazim $(39.42 \%)$., the herbicides: glyphosate $(31.73 \%)$ and paraquat $(30.77 \%)$., and the acaricides: abamectin (54.81\%) and omite (40.38\%) (Table 7).

Table (6): Time of purchasing pesticides and amount of money spent on pesticides' purchase as reported by respondents $(n=104)$.

\begin{tabular}{llcc}
\hline & Item & Frequency of farmers & \% of farmers \\
\hline Time of purchasing & After the appearance of pests & 42 & 40.38 \\
pesticides* & Both At the beginning of the & 37 & 35.58 \\
& growing season & 25 & $\mathbf{2 4 . 0 4}$ \\
\hline Amount of money & Less than 100 & 27 & 25.97 \\
spent on pesticides & $\mathbf{1 0 0 - 4 9 9}$ & 15 & $\mathbf{1 4 . 4 2}$ \\
purchase each year & $\mathbf{5 0 0 - 9 9 9}$ & 09 & $\mathbf{0 8 . 6 5}$ \\
(JD) & $\mathbf{1 , 0 0 0 - 1 , 9 9 9}$ & 07 & $\mathbf{0 6 . 7 3}$ \\
& More than 2,000 & 46 & $\mathbf{4 4 . 2 3}$ \\
\hline
\end{tabular}

*Because multiple choices could be checked by each respondent, percentages do not sum to 100.

Table (7): Types of agrochemicals used in Jordan by respondents $(n=104)$.

\begin{tabular}{|c|c|c|c|}
\hline Group & Pesticide name & Frequency of farmers & \% of farmers* \\
\hline \multirow[t]{21}{*}{ Insecticides } & Chlorpyrifos (Dursban®) & 66 & 63.46 \\
\hline & Methomyl (Lannate®) & 57 & 54.81 \\
\hline & Cypermethrin (Cymbush $\left.{ }^{\circledR}\right)$ & 51 & 49.04 \\
\hline & Imidacloprid (Confidor®) & 50 & 48.08 \\
\hline & Deltamethrin (Decis $\left.{ }^{\circledR}\right)$ & 50 & 48.08 \\
\hline & Oxamyl (Vydate®) & 42 & 40.38 \\
\hline & Methidathion (Supracide®) & 40 & 38.46 \\
\hline & Lambda-cyhalothrin (Karate $®)$ & 36 & 34.62 \\
\hline & Diazinon (Diazinon $\left({ }^{\circledR}\right)$ & 32 & 30.77 \\
\hline & Dimethoate $\left(\right.$ Cygon $\left.{ }^{\circledR}\right)$ & 29 & 27.88 \\
\hline & Malathion (Malathion®) & 28 & 26.92 \\
\hline & Aldicarb (Temik@) & 19 & 18.27 \\
\hline & Methiocarb (Mesurol®) & 16 & 15.38 \\
\hline & Carbofuran (Furadan®) & 14 & 13.46 \\
\hline & Propoxur (Baygon $®)$ & 13 & 12.50 \\
\hline & Permethrin (Ambush®) & 13 & 12.50 \\
\hline & Methyl parathion (Parathion ${ }^{\circledR}$ ) & 12 & 11.54 \\
\hline & Fenvalerate (Pydrin $\left.{ }^{\circledR}\right)$ & 08 & 07.69 \\
\hline & Carbaryl (Sevin®) & 07 & 06.73 \\
\hline & Mevinphos (Phosdrin ${ }^{\circledR}$ ) & 06 & 05.77 \\
\hline & Fenitrothion (Sumithion $®)$ & 05 & 04.81 \\
\hline \multirow[t]{6}{*}{ Fungicides } & Sulphur & 59 & 56.73 \\
\hline & Zineb & 42 & 40.38 \\
\hline & Carbendazim (Carbendamil@) & 41 & 39.42 \\
\hline & Mancozeb (Mancothane $\left.{ }^{\circledR}\right)$ & 33 & 31.73 \\
\hline & Benomyl (Benomyl®) & 32 & 30.77 \\
\hline & Metalaxyl (Vacomil@) & 27 & 25.96 \\
\hline \multirow[t]{3}{*}{ Herbicides } & Glyphosate (Roundup $\left.{ }^{\circledR}\right)$ & 33 & 31.73 \\
\hline & Paraquat (Gramoxone $®$ ) & 32 & 30.77 \\
\hline & 2,4-D (Esterdefore $®)$ & 24 & 23.08 \\
\hline \multirow[t]{3}{*}{ Acaricides } & Abamectin (Vertimec $\left.{ }^{\circledR}\right)$ & 57 & 54.81 \\
\hline & 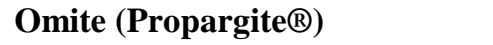 & 42 & 40.38 \\
\hline & Fluazuron & 23 & 22.12 \\
\hline
\end{tabular}

*Because multiple choices could be checked by each respondent, percentages do not sum to 100 . 


\subsubsection{Safety of pesticides}

Respondents reported that they are very highly interested in production quality and quantity (98\%). In addition, more than $90 \%$ of farmers had concern about human health, try to decrease pesticide use and environmental pollution (Table 8). Almost $79 \%$ of the respondents checked the pesticides' level of toxicity before using it. pesticides (2.16) had the least concern by farmers.

The most faced pesticide-related illnesses and injuries reported by respondents are headache/dizziness $(42.31 \%)$, allergy (34.62\%), breathing difficulty $(29.81 \%)$, skin irritation (27.88\%), and chest discomfort (26.92\%). It is well known for respondents that extensive use of pesticides in agriculture can affect natural enemies, birds and wildlife (70.19\%),

Table (8): Some issues related to safety of the pesticides reported by the respondents $(n=104)$.

\begin{tabular}{|c|c|c|c|}
\hline & Task & $\begin{array}{l}\text { Frequency of } \\
\text { farmers }\end{array}$ & $\%$ of farmers* \\
\hline \multirow{7}{*}{ General } & Interest in production quality and quantity & 102 & 98.08 \\
\hline & Care about human health & 98 & 94.23 \\
\hline & Interest in production quantity & 97 & 93.27 \\
\hline & Interest in production quality & 97 & 93.27 \\
\hline & Try to decrease pesticide use & 96 & 92.31 \\
\hline & Care about environmental pollution & 93 & 89.42 \\
\hline & $\begin{array}{l}\text { Care about pesticide effects on } \\
\text { groundwater }\end{array}$ & 82 & 78.85 \\
\hline \multicolumn{2}{|c|}{ Do you check the pesticide level of toxicity before using it? } & 82 & 78.8 \\
\hline
\end{tabular}

*Because multiple choices could be checked by each respondent, percentages do not sum to 100.

Respondents indicated that they have a high level of concern about resistance management by rotating pesticides (mean of 4.06 out of 5) and waiting for safety period of pesticides before harvesting (4.01) (Table 9). Moderate concern was shown by respondents for using adjuvant to improve safety and efficacy of applications (mean: 3.63). Less concern was paid to spraying the same pesticide to the same crop during the season, pesticides combined with non-chemical methods, using selective pesticides and spot spraying for pests (mean: 2.4-2.9). Using bio- contaminate air, soil and water $(66.35 \%)$, and cause death to humans $(62.05 \%)$ (Table 10). However, only $14 \%$ of the farmers know that pesticides can cause diabetes.

The most protective cloths reported by the farmers were nose mask $(77.88 \%)$, washable hat $(71.15 \%)$ and goggles $(69.23 \%)$. Almost $72 \%$ of respondents stored pesticides in special store, while $10.58 \%$ stored them in house. In addition, the majority of the farmers $(57.69 \%)$ burned empty containers, and only $3.85 \%$ recycled them (Table 11).

Table (9): Respondents' knowledge of some selected tasks of pesticides ( $n=104)$.

\begin{tabular}{lc}
\hline Task & $\begin{array}{c}\text { Final point value } \\
\text { (Mean of 5) }\end{array}$ \\
\hline Resistance management by rotating pesticides & 4.06 \\
Wait for safety period of the pesticide before harvesting & 4.01 \\
Using adjuvant to improve safety and efficacy of applications & 3.63 \\
Using systemic pesticides & 3.27 \\
Notified people that pesticides are being used? & 3.12 \\
Using non-persistence pesticides & 3.00 \\
Spray the same pesticide to the same crop during the season & 2.78 \\
Pesticides combined with non-chemical methods & 2.63 \\
Using selective pesticides & 2.62 \\
Spot spraying for pests & 2.43 \\
Time of application depend on traps & 2.25 \\
Using bio-pesticides & 2.16 \\
\hline
\end{tabular}


Table (10): Related pesticides illnesses and injuries reported by respondents $(n=104)$ and knowledge of side effects of extensive use of pesticides in agriculture.

\begin{tabular}{|c|c|c|c|}
\hline & Task & Frequency of farmers & $\%$ of farmers* \\
\hline \multirow{12}{*}{$\begin{array}{l}\text { Pesticide- } \\
\text { related } \\
\text { illnesses and } \\
\text { injuries faced } \\
\text { by } \\
\text { respondents }\end{array}$} & None & 44 & 42.31 \\
\hline & Headache or dizziness & 42 & 40.38 \\
\hline & Allergy & 36 & 34.62 \\
\hline & Breathing difficulty & 31 & 29.81 \\
\hline & Skin irritation & 29 & 27.88 \\
\hline & Chest discomfort & 28 & 26.92 \\
\hline & Blue-red vision & 20 & 19.23 \\
\hline & Secretions from mouth and nose & 19 & 18.27 \\
\hline & Excessive sweating and salivation & 19 & 18.27 \\
\hline & Stomach cramps & 16 & 15.38 \\
\hline & Unable to walk and weakness & 10 & 09.62 \\
\hline & Muscle twitches & 09 & 08.65 \\
\hline \multirow{12}{*}{$\begin{array}{l}\text { Have you } \\
\text { heard that } \\
\text { extensive use } \\
\text { of pesticides } \\
\text { in agriculture } \\
\text { causes? }\end{array}$} & Kill natural enemies, birds and wildlife & 73 & 70.19 \\
\hline & Contaminate air, soil and water & 69 & 66.35 \\
\hline & Death & 65 & 62.05 \\
\hline & Cancer & 61 & 58.65 \\
\hline & Asthma & 58 & 55.77 \\
\hline & Pests resistance & 57 & 54.81 \\
\hline & Destruction of soil microorganisms & 57 & 54.81 \\
\hline & Causing plant injury & 47 & 45.19 \\
\hline & $\begin{array}{l}\text { Immune suppression and hormone } \\
\text { disruption }\end{array}$ & 44 & 42.31 \\
\hline & Decrease plant yield & 38 & 36.54 \\
\hline & Reproductive abnormalities & 36 & 34.62 \\
\hline & Diabetes & 15 & 14.42 \\
\hline
\end{tabular}

*Because multiple choices could be checked by each respondent, percentages do not sum to 100.

Table (11): Protective clothing used, storage of pesticides and fate of empty containers as reported by respondents $(n=104)$.

\begin{tabular}{llll}
\hline & Task & Frequency of farmers & \% of farmers* \\
\hline Protective & Nose mask & $\mathbf{8 1}$ & $\mathbf{7 7 . 8 8}$ \\
clothing used & Washable hat & 74 & 71.15 \\
during & Goggles & 72 & 69.23 \\
pesticides' & Rubber boot & 61 & $\mathbf{5 8 . 6 5}$ \\
application & Thick rubber gloves & 56 & $\mathbf{5 3 . 8 5}$ \\
& Washable overall & 41 & 39.42 \\
& Waterproof overall & 38 & 36.54 \\
& Respirator & 24 & 23.08 \\
\hline Storing & None & 15 & 14.42 \\
pesticides' & Special store & 75 & $\mathbf{7 2 . 1 2}$ \\
place & Housicultural field & 20 & $\mathbf{1 9 . 2 3}$ \\
\hline Fate of empty & Burning & 11 & $\mathbf{1 0 . 5 8}$ \\
containers & Thrown away & 60 & $\mathbf{5 7 . 6 9}$ \\
& Recycling & 41 & 39.42 \\
\hline
\end{tabular}

*Because multiple choices could be checked by each respondent, percentages do not sum to 100. 


\subsubsection{Pesticides' records}

According to respondents, records related to application date and time (54\%) and pesticide name used and rate $(50 \%)$ were the most kept data. Nearly $49 \%$ of respondents said that they kept data on treated crop and pest species. Almost 39 of the farmers did not keep any records (Table 12).

\subsubsection{Pesticides' resources}

There is no single source of information which farmers rely upon for pesticides in their farms although private consultants and pesticides' companies (42\%) were the most popular (Table 13). Other sources formed less than one-fourth of the information sources for farmers. Only $25 \%$ of those responding had been

Table (12): Keeping records by respondents $(n=104)$.

\begin{tabular}{llcc}
\hline IPM practice & Item & $\begin{array}{c}\text { Frequency of } \\
\text { farmers }\end{array}$ & $\begin{array}{c}\text { \% of } \\
\text { farmers* }\end{array}$ \\
\hline Keeping records & Application date and time & $\mathbf{5 6}$ & $\mathbf{5 3 . 8 5}$ \\
& Pesticide name used and rate & 52 & $\mathbf{5 0 . 0 0}$ \\
& Treated crop & 51 & $\mathbf{4 9 . 0 4}$ \\
& Pest species & 51 & $\mathbf{4 9 . 0 4}$ \\
& None & $\mathbf{4 1}$ & $\mathbf{3 9 . 4 2}$ \\
& Adjuvant used & $\mathbf{3 6}$ & $\mathbf{3 4 . 6 2}$ \\
& Meteorological conditions at spraying & $\mathbf{3 0}$ & $\mathbf{2 8 . 8 5}$ \\
& Equipment used & 27 & $\mathbf{2 5 . 9 6}$ \\
& Operator's name & $\mathbf{2 4}$ & $\mathbf{2 3 . 0 8}$ \\
& Personal protective cloths used & $\mathbf{2 0}$ & $\mathbf{1 9 . 2 3}$ \\
\hline
\end{tabular}

*Because multiple choices could be checked by each respondent, percentages do not sum to 100 .

Table (13): Pesticides' resources and required information indicated by respondents $(n=104)$.

\begin{tabular}{|c|c|c|c|}
\hline & Item & Frequency of farmers & $\%$ of farmers* \\
\hline \multirow[t]{7}{*}{ Pest management resources } & Private consultant & 44 & 42.31 \\
\hline & Pesticides' companies & 44 & 42.31 \\
\hline & $\begin{array}{l}\text { Extension meetings, } \\
\text { workshop and newsletters } \\
\text { (MOA) }\end{array}$ & 28 & 26.92 \\
\hline & None & 20 & 19.23 \\
\hline & Websites and books & 12 & 11.54 \\
\hline & $\begin{array}{l}\text { Commercial media } \\
\text { (television, radio, newspaper, } \\
\text { leaflets) }\end{array}$ & 07 & 06.73 \\
\hline & Other resources & 04 & 03.85 \\
\hline $\begin{array}{l}\text { Involvment in pesticides } \\
\text { training or workshop }\end{array}$ & & 26 & 25.00 \\
\hline $\begin{array}{l}\text { Seeking for pesticides } \\
\text { information }\end{array}$ & & 81 & 77.88 \\
\hline \multirow[t]{3}{*}{ Type of information needed } & $\begin{array}{l}\text { Pesticide usage and } \\
\text { application }\end{array}$ & 68 & 65.38 \\
\hline & Pesticide safety & 37 & 35.58 \\
\hline & Others & 07 & 06.73 \\
\hline \multirow[t]{7}{*}{$\begin{array}{l}\text { How would you like to have } \\
\text { information about } \\
\text { pesticides? }\end{array}$} & $\begin{array}{l}\text { Extension meetings, } \\
\text { workshop and newsletters } \\
\text { (MOA) }\end{array}$ & 43 & 41.35 \\
\hline & Written manuals & 42 & 40.38 \\
\hline & Training & 23 & 22.12 \\
\hline & Continuing education & 18 & 17.31 \\
\hline & $\begin{array}{l}\text { Commercial media } \\
\text { (television, radio, newspaper, } \\
\text { leaflets) }\end{array}$ & 16 & 15.38 \\
\hline & Online Information & 14 & 13.46 \\
\hline & Phone calls & 12 & 11.54 \\
\hline
\end{tabular}

*Because multiple choices could be checked by each respondent, percentages do not sum to 100. 
involved in pesticides' training program. Almost $78 \%$ reported seeking for information about pesticides. The most common type of information they looked for is pesticide usage and application (65.38\%) (Table 13). Almost $41 \%$ of the respondents would like to have information about pesticides through MOA or as written manuals.

\subsection{Correlation analysis}

The results indicated that farmer's age is correlated significantly and positively with experience $(\mathrm{r}=0.624, \mathrm{P}<0.01)$, and negatively with education $(\mathrm{r}=-0.180, \mathrm{P}>0.05)$ (Table 14). There was a positive and significant correlation between education of the farmers and knowledge of pesticides use $(\mathrm{r}=0.215, \mathrm{P}<0.05)$. Involvement in pesticides training programs was positively and significantly correlated with education $(\mathrm{r}=0.170, \mathrm{P}=0.05)$ and farm size $(\mathrm{r}=$ $0.205, \mathrm{P}<0.05)$. Reading label was positively and significantly correlated with education $(\mathrm{r}=$ $0.230, \mathrm{P}<0.05)$ and negatively with age $(\mathrm{r}=$ $0.183, \mathrm{P}<0.05)$. There was a positive and significant correlation between involvement in pesticides training and knowledge of pesticides use $(r=0.317, P<0.01)$.
European Union (Dimitri and Oberholtzer, 2005). What is required is to weigh all the risks against the benefits to ensure a maximum margin of safety. This study was set out to analyze farmer beliefs and perceptions in relation to pesticide use for pest control by Jordanian farmers. The current data also discuss issues and trends on various aspects of awareness among farmers toward pesticide use in Jordan. The long experience period in farming (aver. 17 years/farmer) could strengthen our results and give a wider view on awareness of farmers toward pesticide use in Jordan. The present data showed that there is an adequate representation of responses based on cross-section throughout the country, age, experience and education level of farmers and farm size.

In the present study, age (aver. 44-year-old) has negatively and significantly correlated with reading pesticide label. In contrast, education level had a positive and significant correlation with knowledge of pesticides use, reading label and involving in pesticides training programs. In addition, involving in pesticides training has positively and significantly correlated with knowledge of pesticides use. In the same line

Table (14): Some important correlations' analysis between demographics variables of the farmers and particular pesticides' practices/issues $(n=104)$.

\begin{tabular}{lcc}
\hline Correlated variables & $\mathbf{r}$ & Significance \\
\hline Age vs. experience & $\mathbf{0 . 6 2 4 ^ { * * }}$ & $\mathbf{0 . 0 0 0}$ \\
Age vs. education & $\mathbf{- 0 . 1 8 0}$ & $\mathrm{NS}$ \\
Knowledge of pesticides use vs. age & $\mathbf{0 . 0 7 1}$ & $\mathrm{NS}$ \\
Knowledge of pesticides use vs. education & $\mathbf{0 . 2 1 5 ^ { * }}$ & $\mathbf{0 . 0 2 9}$ \\
Knowledge of pesticides use vs. experience & $\mathbf{0 . 0 2 0}$ & $\mathrm{NS}$ \\
Knowledge of pesticides use vs. farm size & $\mathbf{0 . 0 6 3}$ & $\mathrm{NS}$ \\
Involving in pesticides training vs. age & $\mathbf{0 . 1 5 7}$ & $\mathrm{NS}$ \\
Involving in pesticides training vs. education & $\mathbf{0 . 1 7 0}$ & $\mathbf{0 . 0 5 0}$ \\
Involving in pesticides training vs. experience & $\mathbf{0 . 1 4 3}$ & $\mathrm{NS}$ \\
Involving in pesticides training vs. farm size & $\mathbf{0 . 2 0 5}$ & $\mathbf{0 . 0 3 7}$ \\
Reading label vs. age & $\mathbf{- 0 . 1 8 3 *}$ & $\mathbf{0 . 0 5 0}$ \\
Reading label vs. education & $\mathbf{0 . 2 3 0}$ & $\mathbf{0 . 0 1 9}$ \\
Reading label vs. experience & $\mathbf{- 0 . 1 4 0}$ & $\mathrm{NS}$ \\
Reading label vs. farm size & $\mathbf{0 . 0 8 7}$ & $\mathrm{NS}$ \\
Involving in pesticides training vs. knowledge of pesticides & $\mathbf{0 . 3 1 7 ^ { * * }}$ & $\mathbf{0 . 0 1 0}$ \\
\hline
\end{tabular}

NS,* and ** Not significant, significant at 0.05 and 0.01 respectively.

\section{Discussion}

Pesticides are considered a quick and easy solution for controlling agricultural pests. However, pesticide use comes at a significant cost. The economic impact of pesticides on nontarget species including humans has been estimated at approximately 8 billion Dollars annually in developing countries, 10 billion Dollars in the USA and 13 billion Dollars in with our results, Anger et al. (1997) mentioned that the effects of pesticides have been found to vary according to age and education. Our data indicated that a high percent of farmers (66\%) have good knowledge of pesticide use. Good knowledge may be linked to the level of educational attainment (Owusu-Boateng and Amuzu, 2013). Also, Abd Rabou et al. (2002) and Yassin et al. (2002) stated that farmers who 
finished their University level of education were found to have the highest percentage of good knowledge on pesticide use. Farmers with good pesticide knowledge were more inclined to use pesticides according to the recommended guidelines. Farmers with higher education attended training courses on pesticide use and having good communication capabilities with agricultural officials and environmental institutions. Moreover, the highly educated farmers have the ability to fully read the instructions of pesticide use. Abd Rabou et al. (2002) stated that $30 \%$ of farmers have good knowledge of pesticide use, which is lower than what we found. Yassin et al. (2002) stated that younger farmers have the highest good knowledge. This could be attributed to their chance in attending training courses on pesticide use and dealing with pesticides' effectiveness and safety measures.

Our results showed that respondents are very highly interested in production quality and quantity (98\%). In addition, more than $90 \%$ of farmers had concern about human health, environmental pollution and try to decrease pesticide use. It is clear that farmers' perception of harmful effects of chemicals did not influence farmers' decisions in regard to actual decrease of pesticide use. In this regard, Bonabana-Wabbi (2002) mentioned that although $84 \%$ of farmers agreed that pesticides were harmful to crops, animals and humans, 93\% applied pesticides on crops they grew. A possible explanation would be that farmers do not consider health and environmental impacts important considerations when choosing a control approach. Farmers indicated that they have a high concern level about resistance management by rotating pesticides and waiting for safety period of pesticides before harvesting. Our data agree with Owusu-Boateng and Amuzu (2013) who stated that $93 \%$ of farmers waiting for safety period of pesticides before harvesting. In contrast, Al-Saed et al. (2011) mentioned that most of the farmers seldom followed the instructions of safety period.

The data showed that $85 \%$ of the farmers read the label before applying pesticides. In contrast, low percentage of $25 \%$ was reported by Abd Rabou et al. (2002) and only 14\% mentioned by Al-Saed et al. (2011). Low level of education seems to promote risk of pesticide abuse. This may possibly be attributed to difficulties in understanding of use instructions and safety procedures on the product labels
(Owusu-Boateng and Amuzu, 2013). In addition, the reason is that many farmers are careless and others are illiterate. Our data showed that $29 \%$ of the farmers apply pesticides weekly, which in agreement with the findings of Abang et al. (2013). This will promote the misuse of these chemicals and will put both human and environment at risk. Thus, overuse and/or misuse of pesticides by farmers are obvious in the improper estimation of the timing and frequency of application. Irrespective of their health and accumulation of pesticide residues on crops, farmers believe that more spraying of pesticides means more agricultural yield (Wesseling et al., 1997; Abd Rabou et al., 2002). The current results showed that a very high percent $(93 \%)$ of farmers purchased pesticides from local markets, which is in line with the findings of Abd Rabou et al. (2002) who stated a percent of $87 \%$. The majority of farmers (93\%) believed that they will still apply pesticides in the coming years. In regards to type of pesticide used, $74 \%$ of the farmers applied both curative and preventive pesticides against pests, which is close to what Abd Rabou et al. (2002) found $(71 \%)$. Our data showed that $73 \%$ of farmers apply pesticides at the morning, while, only $46 \%$ were reported by Abd Rabou et al. (2002). Middium pesticides' rate was applied by $59 \%$ and higher rate by $38 \%$ of the farmers. In this regard, Al-Saed et al. (2011) stated that farmers are rarely committed with the recommended doses of the pesticides.

The current data showed that farmers purchase pesticides at the beginning of the growing season and after the appearance of pests, which is in complete agreement with findings of Owusu-Boateng and Amuzu (2013). The results of this survey indicated a wide variety of chemicals were being applied and sprayed as pesticides by the farmers. This indicated that farmers depended heavily on use of pesticides for control of different pests, which is in line with findings of Sheikh et al. (2011), Abang et al. (2013) and Owusu-Boateng and Amuzu (2013). This is probably because farmers believe that the only solution to pest problems is to spray more frequently by using different types of pesticides (Dinham, 2003).

Regarding toxicity symptoms associated with pesticides by unsafely application, the results demonstrated that the most faced pesticiderelated illnesses and injuries are headache/dizziness, allergy, breathing difficulty, skin irritation, and chest discomfort. Our data 
agree with the findings of many other researchers in which interviewed farmers mentioned several similar pesticide-related illnesses and injuries (Abd Rabou et al., 2002; Safi, 2002., Abang et al., 2013). Our data indicated that only $15 \%$ of respondents did not wear any protective clothing while the remaining observed wearing protective clothing such as nose masks, washable hat and goggles. In this regard, 75\% (Owusu-Boateng and Amuzu, 2013) and $78 \%$ (Abd Rabou et al., 2002) of respondents stated that they did not wear any health safety measures, which is much higher than what we found in the current study. In addition, several authors demonstrated that despite the high risk and frequency of exposure, many farmers in the developing countries were not use or partially use the protective gear while working with pesticides (Clarke et al., 1997; Yassin et al., 2002). The finding that farmers did not wear protective gear during pesticide application is alarm and needs farmers, environmentalists and governmental officials to stop and think.

The present results showed that $72 \%$ of respondents store pesticides in special store, $19 \%$ in fields and $11 \%$ in house. In addition, the majority of the farmers (58\%) burned empty containers, $39 \%$ throw them away and only $4 \%$ recycled them. In this regard, Owusu-Boateng and Amuzu (2013) stated that the majority of farmers $(85 \%)$ disposed off emptied agrochemical containers by burning them on the farm, leaving them on the farm land, digging up the soil and burying the containers or placing them in the communities' waste bins. About $19 \%$ of farmers stored pesticide containers in the agricultural field, $16 \%$ in the house and $66 \%$ in special store (Abd Rabou et al., 2002). Abang et al. (2013) stated that $70 \%$ of farmers burned the pesticide containers or threw them away on the farm, and $25 \%$ of them store chemicals at home. These methods of disposal pose varying degrees of health risk to both humans and the environment as noted by Recena et al. (2006) and may affirm the exhibition of poor knowledge of issues relating to pesticides. Storage of pesticides in the home will put people at risk. Empty pesticide containers are classified as hazardous wastes and special care is required before and during their disposal. However, it is well known that mismanagement of pesticide containers is common in the developing countries (Wesseling et al., 1997). The prevalence of these methods and practiced may be rooted in low educational attainment which is reflected in poor level of knowledge of issues relating to pesticides.

There is no single source of information which farmers rely upon for pesticide use in their farms although private consultant and pesticides' companies were the most popular. This finding is in line with finding of Al-Zyoud (2014) in which private consultant was the most popular. The current data indicated that $75 \%$ of farmers have never received any training on pesticide use, which is in agreement with the finding of Abang et al. (2013), while Abd Rabou et al. (2002) stated a higher percent of $91 \%$. The absence of farmer training further increases the danger of pesticide misuse. This suggests that designing and implementing educational programs at the sale points are likely to make huge contribution to prevention of pesticides abuse (Owusu-Boateng and Amuzu, 2013).

In conclusion, the results presented here display a lack in awareness of Jordanian farmers toward pesticide use and lack appropriate knowledge on the safe handling and use of pesticides, therefore, underestimated their potential human health and environmental risks. This is represented in overuse, misuse and abuse of pesticides through the improper estimation of the timing and frequency of application, not reading labels on pesticide containers, not wearing protective gear, storage of pesticide containers in home and disposal of empty pesticide containers anywhere. There are strong indications that substantial human health problems are associated with the misuse of pesticides in agriculture in Jordan. The costs of human health effects and environmental problems caused by pesticide use have not been included in the total cost of production and warrant further study to generate appropriate data on which to base policies. There is a need to intensify both extension/farmer relationships and researcher/extension linkage to improve farmers' knowledge on the use of chemicals and strengthen the role of extension services in pest control. Launch of educational and training programs for farmers, public awareness creation and enforcement of laws concerning the use of pesticides to improve safety and awareness of pesticides are of vital importance. A multi-effort from different professional groups, different sectors of the government and nongovernmental organizations is highly recommended. Alternatives to chemical control of pests should be developed, disseminated, and reinforced 
through MOA in Jordan to provide a healthy environment for all.

\section{Acknowledgment}

I wish to express my sincere appreciation for Dr. Amani Al-Dawood for her intensive work in the data processing.

\section{REFERENCES}

Abang A.F., Kouame C.M., Abang M., Hannah R. and Fotso A.K. (2013). Vegetable growers perception of pesticide use practices, cost and health effects in the tropical region of Cameroon. Int 1. J. Agric. Pl. Prod., 4: 873-883.

Abd Rabou A.N., Baroud N.S. and Yassin M.M. (2002). Awareness of farmers towards pesticide use. Egypt. J. Commun. Med., 20: 59-70.

Al-Saed R., Ramlawi A. and Salah A. (2011). A survey on utilization of agricultural pesticides in selected Palestinian districts. Intern. J. Environ. Stud., 68: 519-529.

Al-Zyoud F. (2012). The ladybird predator Serangium parcesetosum Sicard (Col., Coccinellidae). Current status and future perspectives. J. Biol. Cont., 26: 297-313.

Al-Zyoud F. (2014). Adoption range of integrated pest management (IPM) techniques by greenhouse vegetable growers in Jordan. Jordan J. Agric. Sci., 10: $504-525$

Amanullah M. and Hari B.Y. (2011). Evaluation of carbamate insecticides as chemotherapeu-tic agents for cancer. Indian J. Cancer 48: 74-79.

Anger, W., O. Sizemore S., Grossman J. Glasser, R. Letz and R. Bowler (1997). Human neurobehavioral research methods: Impact of subject variables. Environ. Res., 73: 1841.

Bashour I. (2008). Pesticides, fertilizers and food safety. In: Arab Environment: Future Challenges. Tolba, M. and N. Saab (Eds.), Report of the Arab Forum for Environment and Development (AFED) and Technical Publications, Beirut, Lebanon, pp 137-145.

Bonabana-Wabbi, J. (2002). Assessing factors affecting adoption of agricultural technologies: The case of integrated pest management (IPM) in Kumi District, Eastern Uganda, Blacksburg, Virginia. M.Sc. Thesis, pp 146.
Caldas E.D., De Souza M.V. and Jardim A.N.O. (2011). Dietary risk assessment of organophosphorus and dithiocarbamate pesticides in a total diet study at a Brazilian university restaurant. Food Addit. Contam., 28: 71-79.

Clarke E.K., Levy L.S., Spurgeon A. and Calvert L.A. (1997). The problems associated with pesticide use by irrigation workers in Ghana. Occup. Med., 47: 301-308.

Dimitri C. and Oberholtzer L. (2005). Marketled versus government-facilitated growth development of the US and EU organic agricultural sectors. USDA-ARS WRS. http://

www.ers.usda.gov/publications/WRS0505 /wrs0505.pdf.

Dinham B. (2003). Growing vegetables in developing countries for local urban populations and export markets: Problems confronting small-scale producers. Pest Manag. Sci., 5: 575-582.

Espin S., E. Martinez-Lopez., P. GomezRamirez., P. Maria-Mojica and GarciaFernandez A.J. (2010). Assessment of organochlorine pesticide exposure in a wintering population of razorbills (Alca torda) from the Southwestern Mediterranean. Chemosphere 80: 11901198.

Firestone J.A., T. Smith-Weller., G. Franklin., P. Swanson., W.T. Longsteth and Checkoway H. (2005). Pesticides and risk of Parkinson disease: A population-based case-control study. Arch. Neurol., 62: 9195.

Fishel F.M. (2011). Pesticide effects on nontarget organisms. Florida Cooperative Extension Service, Institute of Food and Agricultural Sciences, University of Florida, USA. http://edis.Ifas. ufl.edu.

Frazier L.M. (2007). Reproductive disorders associated with pesticide exposure. J. Agromed., 12: 27-37.

Giri N.P. (1998). Pesticides pollution in vegetable crop in Kathmandu valley. M.Sc. Thesis, Department of Zoology, Tribhuvan University, Nepal.

Glover-Amengor, M. and F.M. Tetteh. (2008). Effect of pesticide application rate on yield of vegetables and soil microbial communities. West Afr. J. Appl. Ecol., 12: $1-7$. 
Goldman L.R. (2007). Managing pesticide chronic health risks: US policies. J. Agromed., 12: 67-75.

Hanke W. and Jurewicz J. (2004). The risk of adverse reproductive and developmental disorders due to occupational pesticide exposure: An overview of current epidemiological evidence. Int'l. J. Occup. Med. Environ. Health 17: 223-243.

Jayashree M. and Singhi S. (2011). Changing trends and predictors of outcome in patients with acute poisoning admitted to the intensive care. J. Trop. Pediatr., 57: 340-346.

Jordan Statistical Yearbook (2012). Department of Statistics/Annual Agriculture Surveys. Issue no. 63, pp 276.

http://www.dos.gov.jo/dos_home_a/main/ cd_yb 2012/pdf/agri.pdf.

Lee D.H., Lee I.K., Song K., Steffes M., Toscano W., Baker B.A. and Jacobs D.R. (2006). A strong dose-response relation between serum concentrations of persistent organic pollutants and diabetes. Diabetes Care 29: 1638-1644.

Market Study-Crop Protection (UC-2805). (2012).

http://www.ceresana.com/en/marketstudies/chemicals/crop-

protection/ceresana-research_marketstudy-crop-protection.html.

Morohashi, M., S. Nagasawa., N. Enya., K. Suzuki., T. Kose and K. Kawata. (2012). Behavior of bromobutide in paddy water and soil after application. Bull. Environ. Contam. Toxicol., 88: 521-525.

Naveed M., Anjum Z.I., Khan J.A., Rafiq M. and Hamza A. (2011). Cotton genotypes morpho-physical factors affect resistance against Bemisia tabaci in relation to other sucking pests and its associated predators and parasitoids. Pak. J. Zool., 43: 229236.

Ngowi A.V.F. (2003). A study of farmers' knowledge, attitude and experience in the use of pesticides in coffee farming. Afr. Newsl. Occupat. Health Safety 13: 56-59.

Ngowi A.V.F., Mbise T.J., Ijani A.S.M., London L. and Ajayi O.C. (2007). Smallholder vegetable farmers in Northern Tanzania: Pesticides use practices, perceptions, cost and health effects. Crop Protect., 26: 1617-1624.

Owusu-Boateng, G. and K.K. Amuzu. (2013). A survey of some critical issues in vegetable crops farming along River Oyansia in Opeibea and Dzorwulu, Accra-Ghana. Glob. Advan. Res. J. Physic. Appl. Sci., 2: 24-31.

Perry M.J., A. Marbell and P.M. Layde (2000). Association of pesticide safely knowledge with beliefs and intentions among farm pesticide applicators. J. Occup. Environ. Med., 42: 187-193.

Raipulis J., Maija M. and Balode M. (2009). Toxicity and genotoxicity testing of roundup. Proc. Latvian Acad. Sci., Section B, 63: 29-32.

Recena M.C., Caldas E.D., Pires D.X. and Pontes E.R. (2006). Pesticides exposure in Culturama, Brazil-knowledge, attitudes, and practices. Environ. Res., 102: 230236.

Safi J.M. (2002). Association between chronic exposure to pesticides and recorded cases of human malignancy in Gaza Strip (1990- 1999). Sci. Total Environ., 284: 75-84.

Samiee A., Rezvanfar A. and Faham E. (2009). Factors influencing the adoption of integrated pest management (IPM) by wheat growers in Varamin County, Iran. Afr. J. Agric. Res., 4: 491-497.

Sheikh S.A., Nizamani S.M., Jamali A.A. and Kumbhar M.I. (2011). Pesticides and associated impact on human health: A case of small farmers in southern Sindh. Pak. J. Phar. Nutr. Sci., 1: 82-86.

Song F. and Swinton S.M. (2009). Returns to integrated pest management research and outreach for soybean aphid. J. Econ. Entomol., 102: 2116-2125.

Sorensen S.R., Ronen Z. and Aamand J. (2011). Isolation from agricultural soil and characterization of a Sphingomonas sp. able to mineralize the phenylurea herbicide isoproturon. Appl. Environ. Microbiol., 67: 5403-5409.

SPSS Statistical Product and Service Solutions INC. (1997). SIGMASTAT 2.03: SigmaStat Statistical software user's manual. Chicago, USA.

Tanabe S., Senthilkumar K., Kannan K. and Subramanian A.N. (1998). Accumulation features of polychlorinated biphenyls and organochlorine pesticides in resident and migratory birds from south India. Arch. Environ. Contam. Toxicol., 34: 387-397.

Weichenthal S., Moase C. and Chan P. (2010). A review of pesticide exposure and cancer 
incidence in the agricultural health study cohort. Environ. Health Perspect., 118: 1117-1125.

Wesseling C., McConnell R., Partanen T. and Hogstedt C. (1997). Agricultural pesticide use in developing countries: Health effects and research needs. Int. J. Health Serv., 27: 273-308.
Yassin M.M., Abu Mourad and T.A. and Safi J.M. (2002). Knowledge, attitude, practice, and toxicity symptoms associated with pesticide use among farm workers in the Gaza Strip Occup. Environ. Med., 59: 387- 394.

Zar J. (1999). Bio-statistical analysis. Prentice Hall, Upper Saddle River, NJ, USA. pp 663.

$$
\begin{aligned}
& \text { الاستخدام العشوائي والرش غير الآمن للمبيدات بوساطة مزارعي الخضار والفاكهة ـ الأردن } \\
& \text { فراس احمد الزيود } \\
& \text { قسم وقاية النبات و المكافحة المتكاملة للآفاتـ كلية الزر اعةـ جامعة مؤنةـ الكركـ الأردن }
\end{aligned}
$$

ملنص

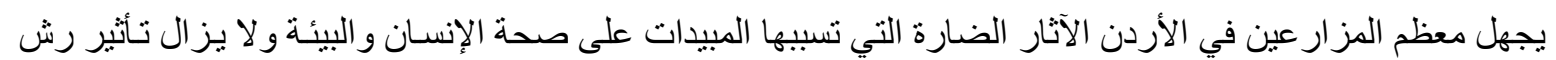

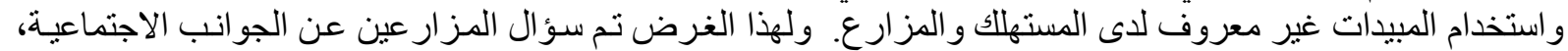

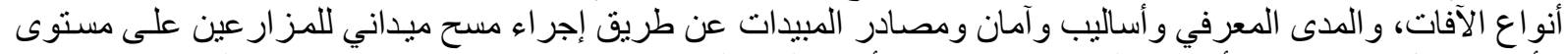

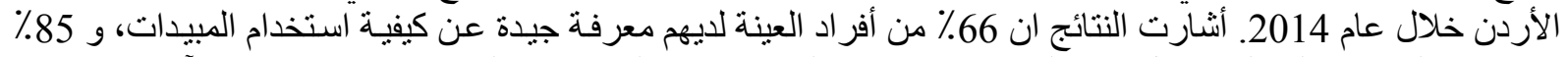

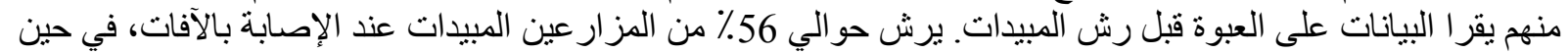

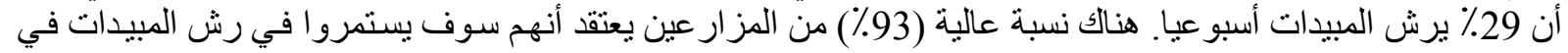

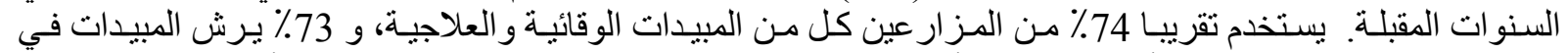

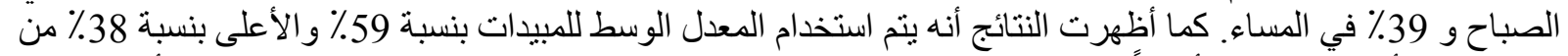

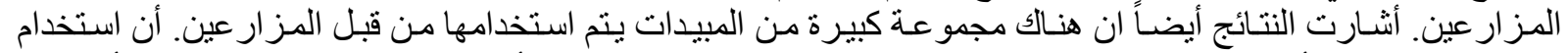

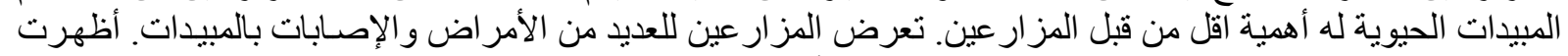

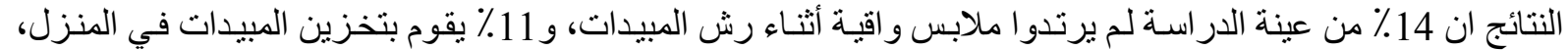

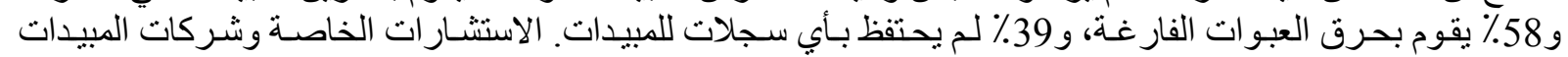

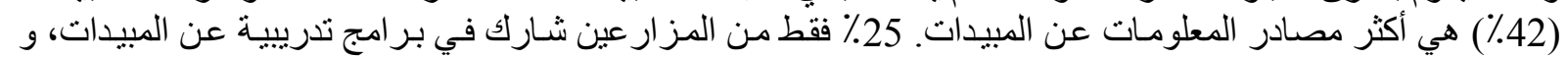

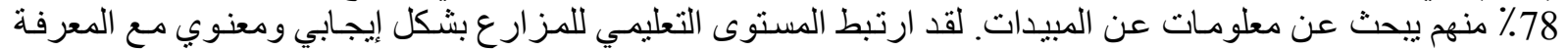

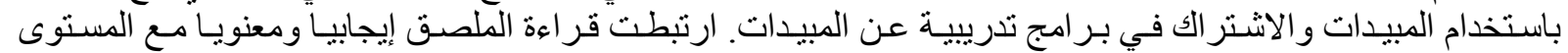

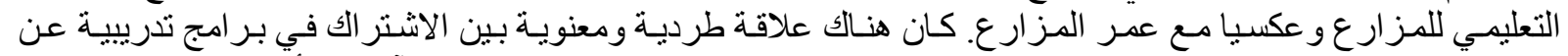

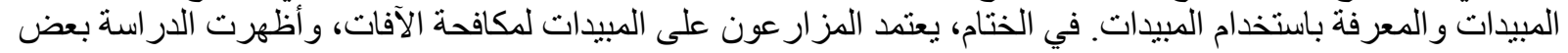

الإفراطوسوء في استخدام المبيدات. 